\title{
The frontal weapon of the termite Armitermes euamignathus Silvestri (Isoptera, Termitidae, Nasutitermitinae)
}

\author{
Ana Maria Costa-Leonardo ${ }^{1}$
}

\begin{abstract}
Frontal weapon is the term used to designate the apparatus consisting of frontal gland and associated structures that participate in the chemical defense of termite soldiers. The ultrastructure of the frontal gland and the scanning microscopy of the soldier head was investigated in the termite Armitermes euamignathus Silvestri, 1901. Campaniform sensilla was not observed but there were 80 to 100 sensory bristles around the frontal pore. The glandular epithelium shows only class 1 cells according to the classification of NOIROT \& QUENNEDEY $(1974,1991)$. The glandular cells are characterized by apical microvilli, a basal labyrinth and a large quantity of smooth endoplasmic reticulum which forms dense zones throughout the cytoplasm. The secretion is concentrated mainly in the basal pole of the cell and consists of large lipid droplets. The secretory epithelium is covered by a thick apical cuticle composed of a thin outer epicuticle, a layer of epicuticular filaments and a dense procuticle. The cytological results concerning the frontal pore showed a reduced cuticle and the presence of a subcuticular space where the lipid droplets are accumulated. The lack of class 3 cells and the presence of an intrinsic musculature are two anatomical features of the A. euamignathus frontal gland that will be important in the phylogenetic relationships of the Nasutitermitinae.

KEY WORDS: Isoptera, Armitermes euamignathus, frontal weapon, frontal gland, exocrine glands
\end{abstract}

Armitermes euamignathus Silvestri, 1901 is a mound builder termite that presents a high incidence in the cerrado region of Brazil (DOMINGOS 1985; GONTIJO \& DOMINGOS 1991).

Frontal weapon is the term used by QuenNEDEY \& DELIGNE (1975) to designate the apparatus consisting of the frontal gland and associated structures that participate in the chemical defense of termite soldiers. The frontal weapon is constituted by the frontal gland, the frontal pore and cephalic structures of the front, clypeus and labrum (DELIGNE et al. 1981).

The present research is an analysis of the frontal pore through scanning electron microscopy and an ultrastructural study of the frontal gland in A. euamignathus soldiers.

\section{MATERIAL AND METHODS}

The study was conducted on soldiers of $A$. enamignathus from cerrado vegetation located in Corumbataí, São Paulo, Brazil. Voucher specimens are deposited in the Isoptera collection of the CEIS (Centro de Estudo de Insetos Sociais) of UNESP (Universidade Estadual Paulista), Rio Claro, São Paulo.

1) Departamento de Biologia, Instituto de Biociências, Universidade Estadual Paulista. Caixa Postal 199, 13506-900, Rio Claro, São Paulo, Brasil. E-mail: amcl@rc.unesp.br 
For scanning electron microscopy, heads of soldiers were dehydrated in 70 , 95 and $100 \%$ ethanol for 2 hours each and then air-dried in a desiccator overnight or were critical-point dried in a Sorvall apparatus. The material was mounted on stubs with silver paste, coated with ca $200 \mathrm{~nm}$ of gold using a sputter-coater, and was examined with a Perkin-Elmer ETEC scanning electron microscope operated at an accelerating voltage of $10 \mathrm{Kv}$.

For ultrastructural analysis, the isolated frontal gland was fixed in 3\% glutaraldehyde buffered with sodium cacodylate, post-fixed in $1 \%$ osmium tetroxide in the same buffer and embedded in epon-araldite. Thin sections were obtained with a Porter-Blum ultramicrotome, stained with uranyl acetate and lead citrate and examined in a Zeiss EM9 S2 electron microscope.

\section{RESULTS}

The soldiers of A. euamignathus have sharp-pointed mandibles and a relatively long nasus that ends in a frontal pore through which they expel the contents of the frontal gland (Figs 1-5). Around the frontal pore there are 80 to 100 sensory bristles which can be long or short (Figs 4-5). The long bristles are about $40 \mu \mathrm{m}$ in length and the short bristles, which are more abundant, are less than $17 \mu \mathrm{m}$ long. Campaniform sensilla are not observed near the frontal pore of the A. euamignathus soldiers.

The frontal gland of $A$. euamignathus is shaped like a pouch and the ultrastructure of the glandular epithelium shows only class I cells according to the classification of NOIROT \& QUENNEDEY $(1974,1991)$.

The ultrastructure of one glandular cell is shown in figure 6. The glandular cells are covered with a thick apical cuticle which lines a space inside the frontal gland that works as a reservoir. This reservoir stores prominent secretion produced by the glandular epithelium. In the thick cuticle, it was possible to distinguishe three layers: a thin and pitted cuticle corresponding to the outer epicuticle, a layer of epicuticular filaments and an inner and dense cuticle corresponding to the procuticle (Fig. 7). The cuticle is up to 0,7 to $1,8 \mu \mathrm{m}$ thick with a procuticle of about $0,5 \mu \mathrm{m}$.

Below the cuticle there are short and parallel microvilli with exocytosis vesicles scattered among them.

Numerous mitochondria are scattered through the cytoplasm, sometimes being thin and long, mainly when the cytoplasm shows irregular vacuolation. The presence of multilamellar bodies below the microvilli is common (Fig. 7). Small Golgi bodies (Fig. 8) and free ribosomes are also present in the glandular cytoplasm but are not so evident as the developed smooth endoplasmic reticulum.

The structure of the cuticle varies along the length of the gland. In the nose, near the frontal pore, it is possible to observe a reduced cuticular layer and a subcuticular cavity commonly containing lipid secretion (Figs 9, 10).

The glandular cytoplasm is rich in vesicular smooth endoplasmic reticulum and also contains some fragments of granular endoplasmic reticulum (Fig. 11). The secretion is mainly concentrated in the basal part of the cells and consists of large and spherical lipid droplets which are weakly electrondense (Fig. 6). 

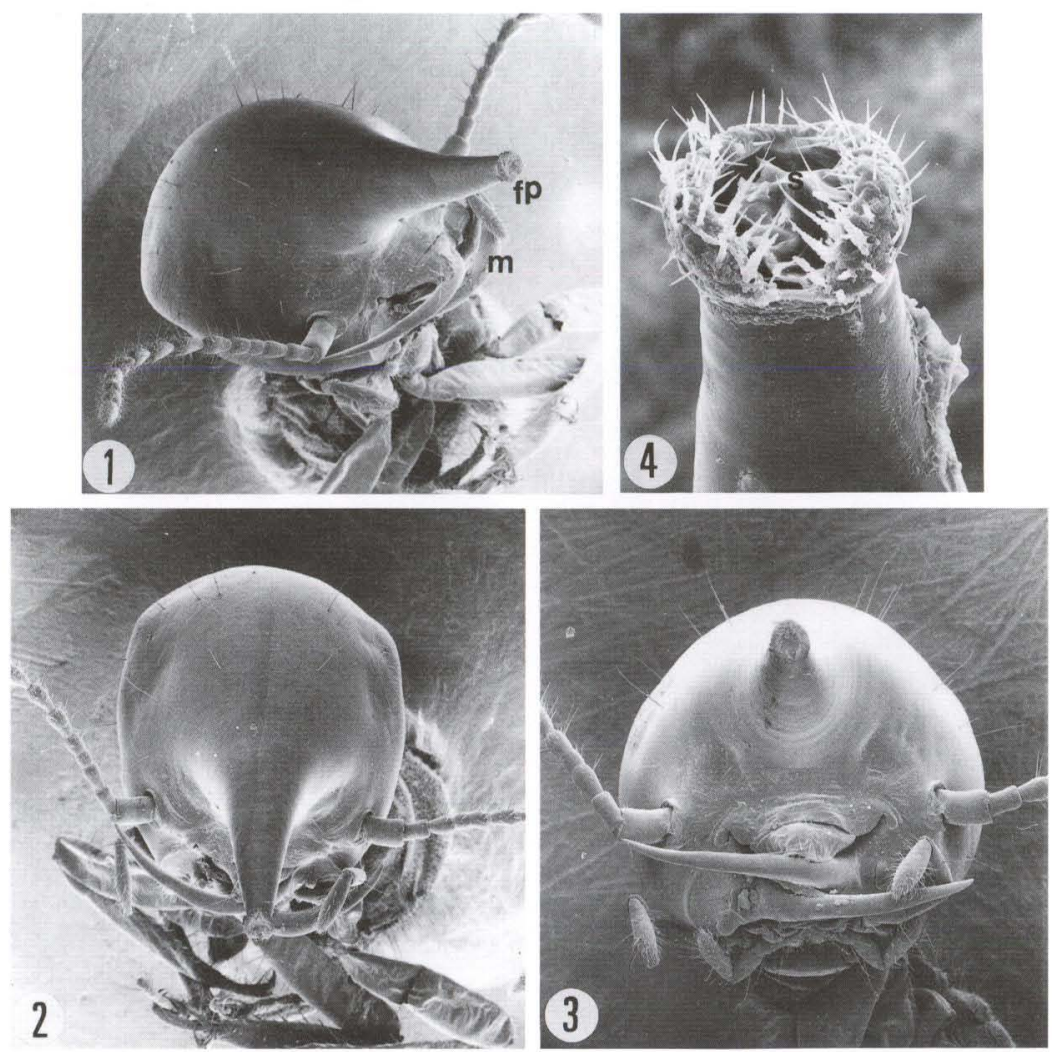

Figs 1-4. Scanning electron microscopy of the A. euamignathus soldier. (1-3) Soldier head; (4) detail of the frontal pore. (fp) Frontal pore, $(\mathrm{m})$ mandible, $(\mathrm{s})$ secretion.

The contact between the glandular cells is convoluted and constituted by an apical zona adhaerens followed by septate junctions (Fig. 9). Many invaginations of the plasma membrane are associated with multilamellar bodies, secretion (Fig. 6) and mitochondria in the basal pole of glandular cells. The basal membrane is thick and is enveloped by the musculature which stimulates the mechanism of glandular extrusion. A tenuous connective tissue connects the glandular epithelium with the muscular fibers that are located around the frontal gland (Fig. 6).

A cross section of the nasus shows two concentric cuticular layers (Fig. 12). The inner layer corresponds to the glandular cuticle placed above the class 1 cells of the epithelium. The external layer is thick and corresponds to the nasus cuticle. A secretion with a filamentous appearance is stored above the glandular cuticle (Fig. 12).

\section{DISCUSSION}

Armitermes euamignathus is a termite that has a mechanical and chemical defense. The mandibles represent the mechanical defense and the frontal gland the chemical defense (Deligne et al. 1981; PrESTWICH 1984). 




Fig. 5. Nasus ending showing the long (two arrows) and short (one arrow) sensorial bristles located around the frontal pore.

Several types of sensory bristles are found associated with the frontal weapon of the termite soldier (DELIGNE et al. 1981; QUENNEDEY 1984) but it is difficult to determine their function without electrophysiological studies. Nevertheless, it is clear that some bristles should be mechanosensory and others chemoreceptors. Since the termite soldiers are blind, the campaniform sensilla and the mechanosensory bristles inform them about the localization of the enemy while the chemoreceptors inform them about the fluency of the secretion (DELIGNE et al. 1981). Campaniform sensillae were not observed in A. euamignathus, but they are found in other Nasutitermitinae soldiers (COSTA-LEONARDO 1998). 


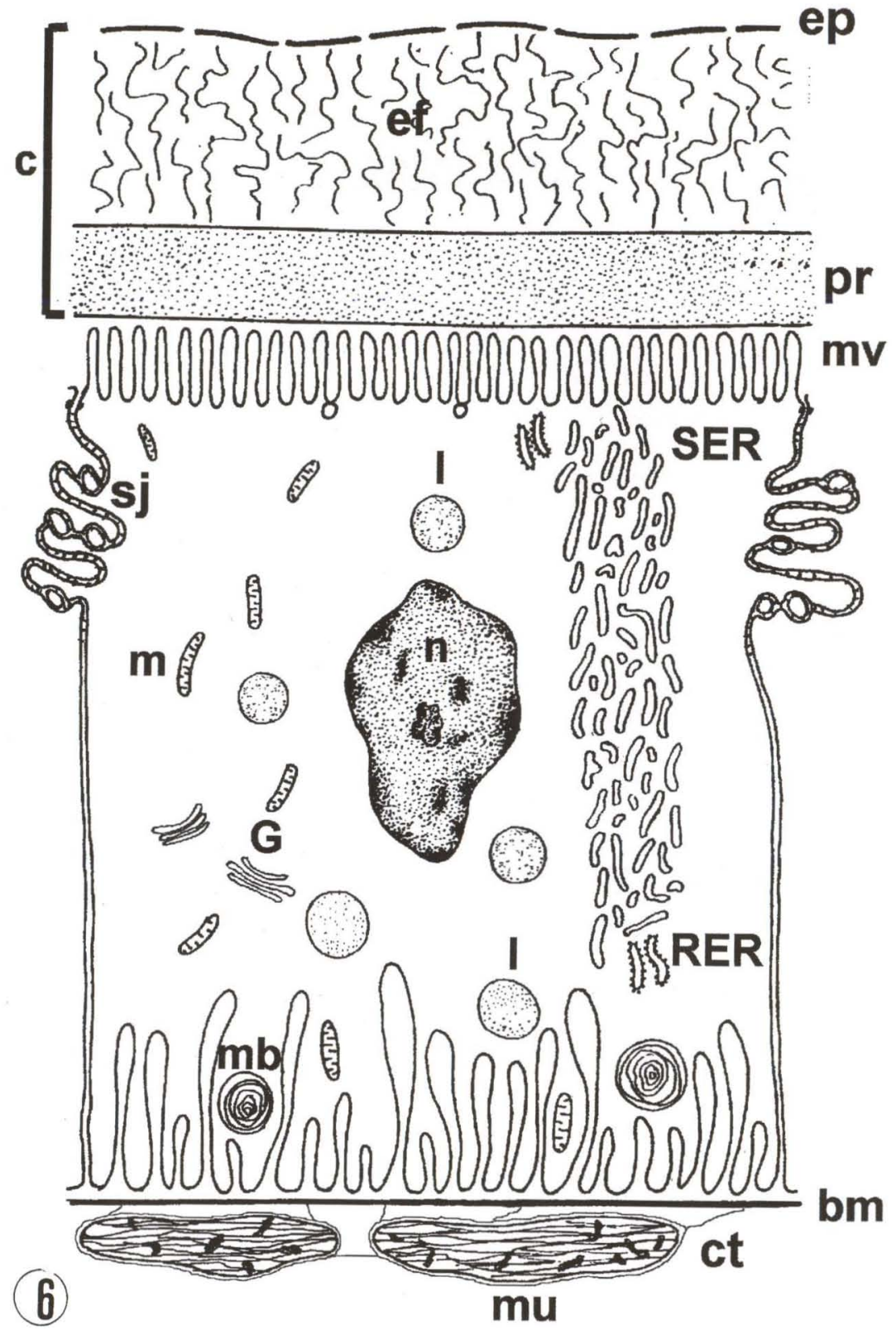

Fig. 6. Ultrastructure schema of the glandular cell. (bm) Basal membrane, (c) cuticle, (ct) connective tissue, (ef) epicuticular filaments, (ep) epicuticle, (G) Golgi body, (I) lipid secretion, $(\mathrm{m})$ mitochondria, $(\mathrm{mu})$ musculature, $(\mathrm{mv})$ microvilli, $(\mathrm{mb})$ multilamelar bodies, $(\mathrm{n})$ nucleus, $(\mathrm{pr})$ procuticle, (RER) rough endoplasmic reticulum, (SER) smooth endoplasmic reticulum, (sj) septate junctions. 

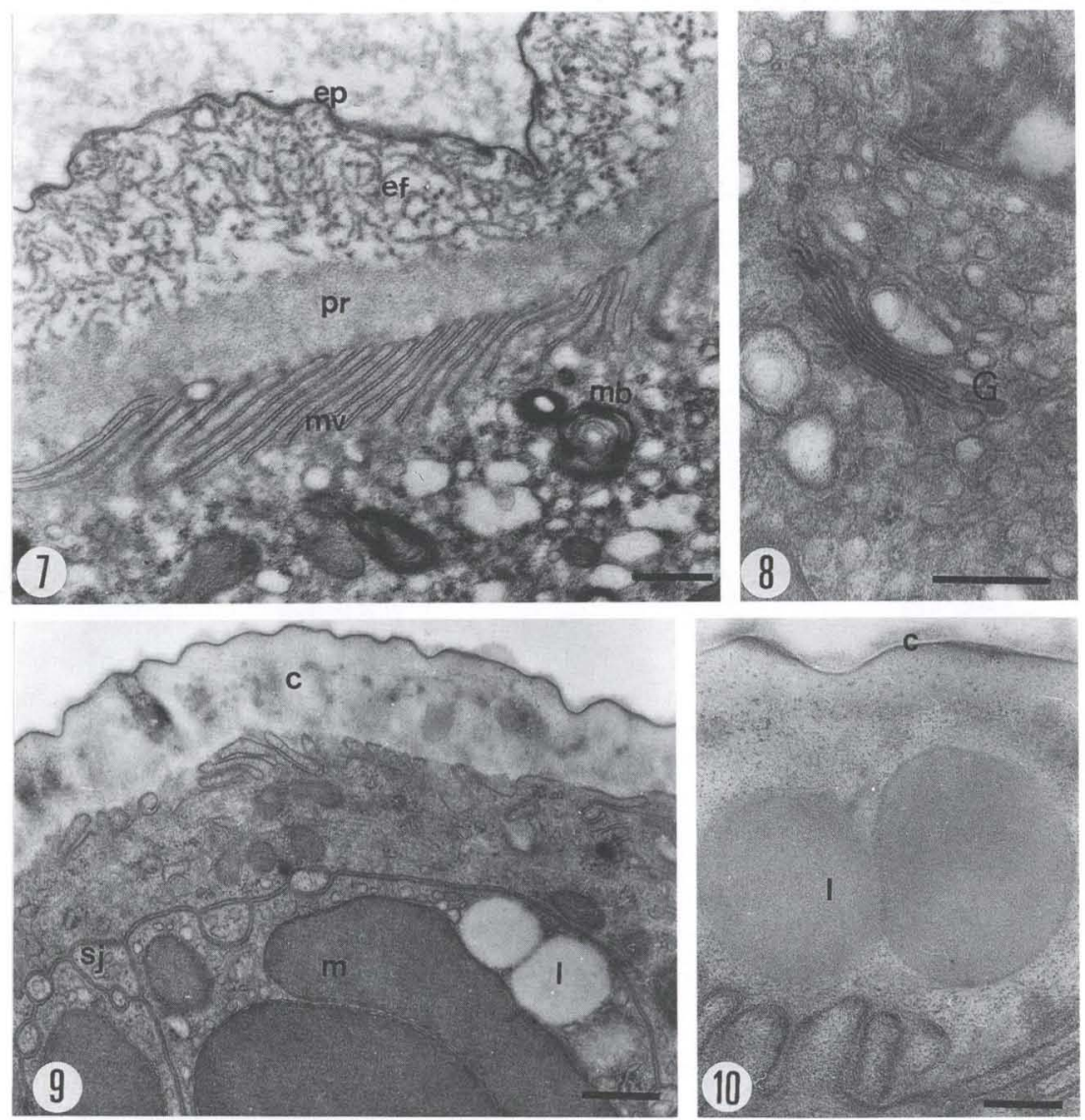

Figs 7-10. Ultrastructure of the glandular cells. (7) Apical portion of the glandular cell; (8) detail of Golgi body; (9) apical portion of the nasus glandular cell; (10) lipid droplets in a subcuticular cavity. (c) Cuticle, (ef) epicuticular filaments, (ep) epicuticle, (G) Golgi body, (I) lipid droplet, $(\mathrm{m})$ mitochondria, (mb) multilamellar body, (mv) microvilli, (pr) procuticle, (sj) septate junctions. Bar $=0,5 \mu \mathrm{m}$.

The frontal gland of $A$. euamignathus is restricted to the insect head (CoSTA-LEONARDO \& DE SALVO 1987), it is only constitued by class I glandular cells and has cytological characteristics similar to those present in other termite exocrine glands with lipid secretion (QUENNEDEY 1972, 1998; COSTA-LEONARDO 1992, 1998).

The cuticle above the glandular epithelium in Trinervitermes geminatus soldiers is thicker than that observed in A. euamignathus, but the cuticular layers are similar in both species (QUENNEDEY 1984).

The subcuticular space observed here is common in the frontal gland of other termites (QUENNEDEY 1984) and in the insect glands which secrete waxy substances (FOLDI 1981; WAKU \& FOLDI 1984). These spaces store the secretion outside the 


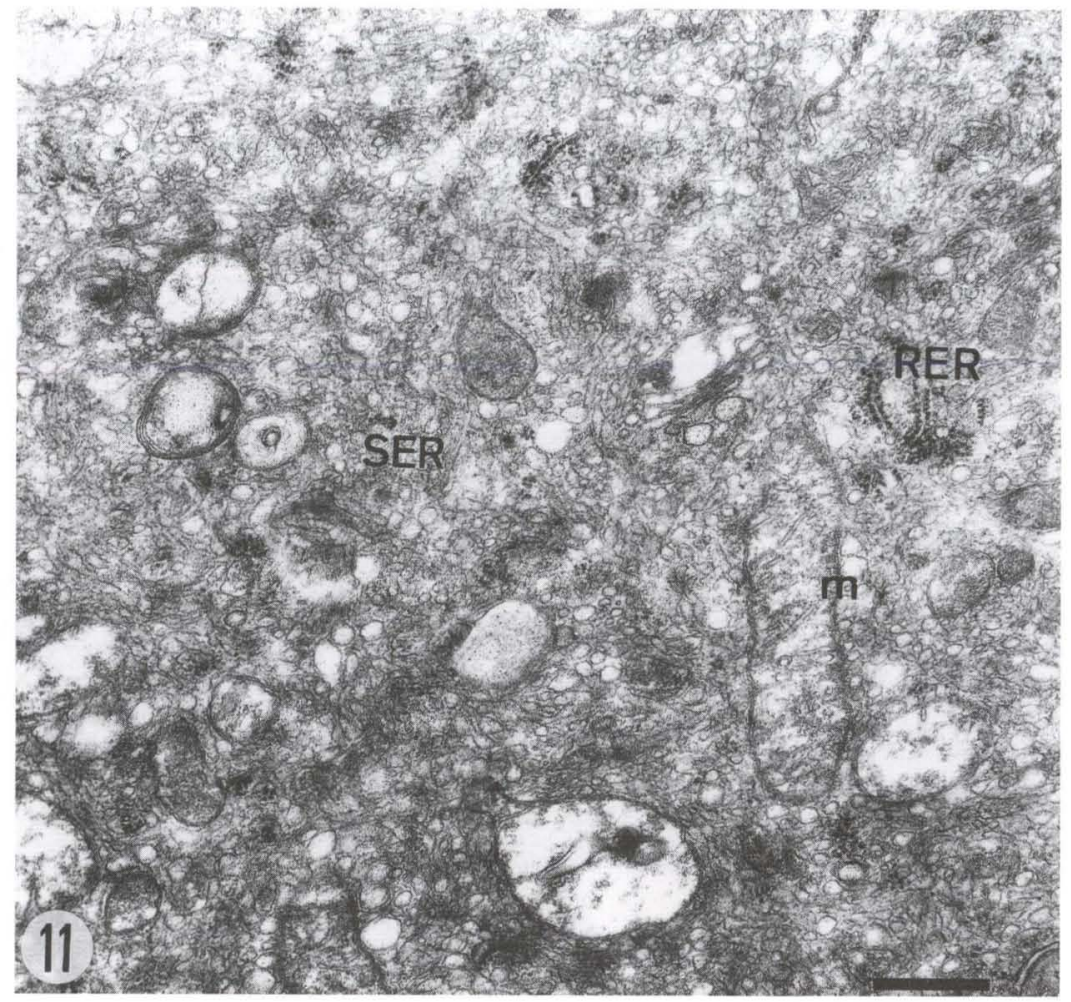

Fig. 11. General view of the glandular cytoplasm. (m) Mitochondria, (RER) rough endoplasmic reticulum, (SER) smooth endoplasmic reticulum. Bar $=0,5 \mu \mathrm{m}$.

cell and allow various chemical reactions to occur inside them. According to QUENNEDEY (1998) the extracellular spaces developed between two cuticular layers are associated with a reduction in some cuticular layers. Here, the epicuticle consists of only a thin layer of cuticuline that allows easier transit of the secretion.

The frontal secretion of A. euamignathus has a slight toxic effect on ants but it contains allomones that reduce their raiding efficiency (HowSE 1984). It is well established that in this species the frontal secretion consists mainly of hydrocarbons (PRESTWICH 1982). The hydrocarbon pheromones of many insects, as some Lepidoptera and Diptera, are synthesized from fatty acids in a series of steps (CHAPMAN 1998). A great development of the smooth endoplasmic reticulum relationed to lipophilic compounds was already found in ant exocrine glands that produce hydrocarbons (BILLEN 1986, 1990). The smooth endoplasmic reticulum is abundant in defensive glands, in the scent glands of Lepidoptera, and in the glands that secret lipids or pheromones (ARAUJO \& PASTEELS 1985; COSTA-LEONARDO 1992, 1998; PERCY-CunNingham \& MACDONALD 1987; QuenNEDEY 1972, 1998).

The septate junctions are a peculiarity of arthropods and their principal characteristic is the presence of septa in the intercellular space. The structure of 


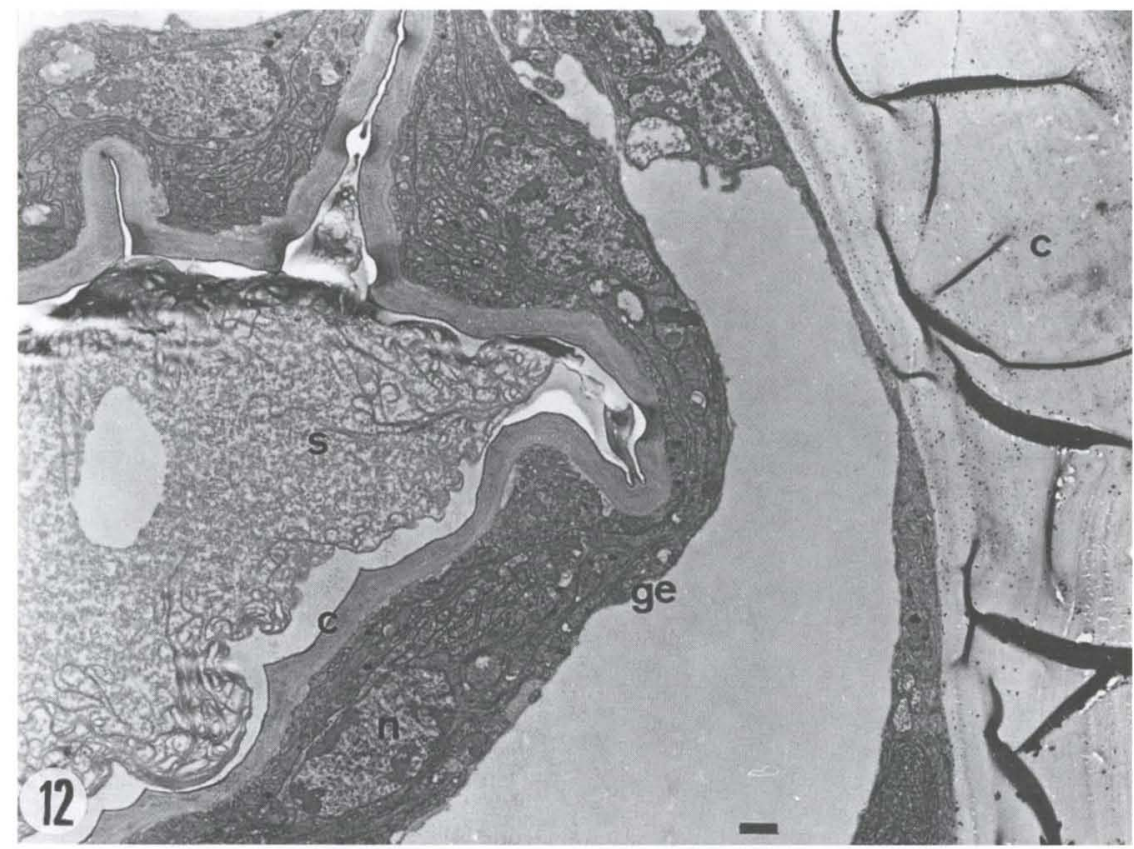

Fig. 12. Cross section of the nasus. Around the glandular epithelium there is a ring of a tick cuticular layer. (c) Cuticle, (ge) glandular epithelium, (n) nucleus, (s) secretion. Bar $=1 \mu \mathrm{m}$.

septate junctions varies in invertebrates, but they always form a continuous belt around the apical region of epithelial cells. As occur in A. euamignathus, the septate junctions are often associated with other types of junctions such as the zona adhaerens and gap junctions (LANE et al. 1994).

In conclusion, the ultrastructure of the frontal gland of $A$. enamignathus showed various cytological characteristics such as richness in smooth endoplasmic reticulum, lipid droplets, apical microvilli, presence of an extracellular space that seems to be related to the chemical nature of the frontal secretion in this termite. Some of these characteristics have been already described in other type 1 cells of termite glands (COSTA-LEONARDO 1992, 1998; QUENNEDEY 1998). As suggested in the past by the ligth microscopy (CosTA-Leonardo \& DE SALvo 1987) the musculature located around the frontal gland seems intrinsic because it is connected with the glandular epithelium throught connective tissue. The lack of class 3 cells and the presence of an intrinsic musculature are two anatomical features of the $A$. euamignathus frontal gland that will be important in the phylogenetic relationships of the Nasutitermitinae.

ACKNOWLEDGEMENTS. The author thanks Dr. Kathleen S. Shields for help with the scanning microscopy and $\mathrm{CNPq}$ for financial support. 


\section{REFERENCES}

Araujo, J. \& J.M. Pasteels. 1985. Ultrastructure de la glande défensive de Drusilla canaliculata Fab. (Coleoptera, Staphylinidae). Arch. Biol. 96: 81-99.

BILLEN, J. 1986. Comparative morphology and ultrastructure of the Dufour gland in ants (Hymenoptera, Formicidae). Entomol. Gener. 11: 165-181.

- 1990. Morphology and ultrastructure of the Dufour's and venom gland in the ant Myrmecia gulosa (Fabr.)(Hymenoptera: Formicidae). Aust. Jour. Zool. 38:305-315.

Chapman, R.F. 1998. The insects. Structure and Function. Cambridge, Cambridge Univ. Press, 770p. Costa-Leonardo, A.M. 1992. The secretory epithelium of the frontal gland in Velocitermes sp. soldiers (Isoptera, Termitidae). Naturalia 17: 99-109.

. 1998. Morphology of the frontal weapon in the soldier caste of Cornitermes cumulans (Isoptera, Termitidae). Rev. Bras. Ent. 41(2-4):195-197.

Costa-Leonardo, A.M. \& C.R. DE Sal.vo. 1987. A comparative study of the frontal glands in three species of Brazilian termite soldiers (Isoptera, Termitidae). Revta bras. Ent. 31 (3): 465-71.

Deligne, J., A. Quennedey \& M.S. Blum. 1981. The enemies and defense mechanisms of termites, p. 1-76. In: H.R. Hermann (Ed.). Social Insects. New York, Academic Press, Vol. 2, 491 p.

Domingos, D.J. 1985. Densidade e distribuição espacial de ninhos de duas espécies de Armitermes (Isoptera, Termitidae) em cinco formações vegetais do cerrado. Rev. Brasil. Biol. 45 (3): 233-240.

FoLDI, I. 1981. Ultrastructure of the wax-gland system in subterranean scale insects (Homoptera, Coccoidea, Margarodidae). Jour. Morphol. 168: 159-170.

Gontuo, T.A. \& D.J. Domingos. 1991. Guild distribution of some termites from cerrado vegetation in south-east Brazil. Jour. Trop. Ecol. 7: 523-529.

Howse, P.E. 1984. Sociochemicals of termites, p. 475-519. In: W.J. Bel. \& R.T. CARDÉ (Eds). Chemical Ecology of Insects. New York, Chapman \& Hall, 519p.

Lane, N.J.; G. Martinucci; R. Dallai \& P. Burighel. 1994. Electron microscopic structure and evolution of epithelial junctions, p. 23-43. In: S. CITI (Ed.). Molecular mechanisms of epithelial cell junctions: from development to disease. Austin, R.G. Landes Co., 308p.

Notrot, C. \& A. QuenNedey. 1974. Fine structure of insect epidermal glands. Annu. Rev. Entomol. 19: $61-80$.

- 1991. Glands, gland cells, glandular units: Some comments on terminology and classification. Ann. Soc. Ent. Fr., n.s., 27: 123-128.

Percy-Cunningham, J.E. \& J.A. MacDonald. 1987. Biology and ultrastructure of sex pheromone-producing glands, p. 27-75. In: G.D. Prestwich \& G.J. Blomquist (Eds). Pheromone Biochemistry. New York, Praeger Scientific, 565p.

Prestwich, G.D. 1982. From tetracycles to macrocyles. Tetrahedron 38 (13): 1911-1919.

1984. Defense mechanisms of termites. Ann. Rev. Entomol. 29: 201-232.

QuENNEDEY, A. 1972. Les glandes exocrines des termites. III. Structure fine de la glande sternale de Trinervitermes geminatus Wasman (Termitidae, Nasutitermitinae). Z. Zellforsch. 130: 205-218.

- 1984. Morphology and ultrastructure of termite defense glands, p. 151-200. In: H.R. Hermann (Ed.). Defensive mechanisms in social insects. New York, Praeger Scientific, 259p.

- 1998. Insect epidermal gland cells: ultrastructure and morphogenesis, p. 177-207. In: F.W.

HARRISON (Ed.). Microscopic Anatomy Invertebrates. New York, Wiley-Liss Inc. Press, Vol. 11, $381 \mathrm{p}$.

QuenNEDEY, A. \& J. Deligne. 1975. L'arme frontale des soldats de termites. I. Rhinotermitidae. Ins. Soc. 22 (3): 243-267.

WAKU, Y. \& A.I. FOLDI. 1984. The fine structure of insect glands secreting waxy substances, p. 303-322. In: R.C. KING \& H. AKAI (Eds). Insect ultrastructure. New York, Plenum Press, Vol. 2, 485p.

Recebido em 17.VIII.2000; aceito em 15.V.2001. 